\title{
Hubungan antara Kreativitas Siswa dengan Hasil Belajar Matematika Siswa Kelas VIII SMP N 1 X Koto Di Atas Kabupaten Solok Tahun Pelajaran 2017/2018
}

\author{
Endang Mayora ${ }^{1}$, Junaidi ${ }^{2}$, Rusdi $^{3}$ \\ ${ }^{1}$ Program studi pendidikan matematika, IAIN Bukit Tinggi \\ ${ }^{1,2}$ Program studi pendidikan matematika, LAIN Bukit Tinggi \\ e-mail: endangmayora3@gmail.com
}

\begin{abstract}
ABSTRAK. Penelitian ini bertujuan untuk mengetahui apakah terdapat hubungan yang signifikan antara kreativitas dengan hasil belajar matematika. Jenis penelitian yang digunakan adalah penelitian korelasional dengan sifat Ex Post Facto. Data pada penelitian ini berupa skor angket kreativitas dan nilai akhir matematika siswa kelas VIII. Teknik analalisis data yang digunakan dengan uji Z. Hasil penelitian ini diperoleh $Z_{0}=3,225585$ dan $Z_{\text {tabel }}=1,95996398$, pada taraf nyata $a=0,05$. Hal ini menunjukkan bahwa $Z_{0}>Z_{\text {tabel }}$ yang berarti bahwa terdapat hubungan signifikan antara kreativitas siswa dengan hasil belajar matematika siswa kelas VIII SMP N 1 X Koto Di Atas Kabupaten Solok Tahun Pelajaran 2017/2018.
\end{abstract}

Kata kunci: hubungan, angket kreativitas, hasil belajar matematika

\section{PENDAHULUAN}

Pendidikan adalah usaha sadar dan terencana untuk mewujudkan suasana belajar dan proses pembelajaran agar siswa secara aktif mengembangkan potensi dirinya untuk memiliki kekuatan spiritual, keagamaan, pengendalian diri, kepribadian, kecerdasan, akhlak mulia, serta keterampilan yang diperlukan dirinya, masyarakat, bangsa dan negara.Diungkapkan dalam Garis-garis Besar Program Pengajaran (GBPP) matematika, bahwa tujuan umum diberikanya matematka pada jenjang pendidikan dsar dan menengah meliputi dua hal, yaitu:

1. Mempersiapkan siswa agar sanggup menghadapi perubahan-perubahan keadaan di dalam kehidupan dan di dunia yang selalu berkembang, melalui latihan bertindak, atas dasar pemikiran logis, rasional, kritis, cermat, jujur, efektif dan efesien.

2. Mempersiapkan siswa agar dapat menggunakan matematika dan pola pikir matematika dalam kehidupan sehari-hari dan mempelajari berbagai ilmu pengetahuan (Erman Suherman, 2003)

Secara rinci tujuan Khusus pembelajaran matematika pada masing-masing satuan pendidikan diungkapkan dalam masing-masing GBPP matematika. Adapun tujuan pembelajaran matematika di SMP adalah sebagai berikut:

1. Siswa memiliki kemampuan yang dapat dialihgunakan melalui kegiatan matematika.

2. Siswa memiliki pengetahuan matematika sebagai bekal untuk melanjutkan ke pendidikan menengah.

3. Siswa memiliki keterampilan matematika sebagai peningkatan dan perluasan dari matematika sekolah dasar untuk dapat digunakan dalam kehidupan sehari-hari.

4. Siswa memiliki pandangan yang cukup luas dam memilki sikap logis, cermat dan disiplin serta menghargai kegunaan matematika (Erman Suherman, 2003)

Usaha untuk mencapai tujuan pembelajaran matematika tersebut di atas telah banyak dilakukan oleh pemerintah, seperti seminar dan pelatihan guru, penyempurnaan kurikulum dan lain-lain. Usaha tersebut semata-mata untuk memajukan pendidikan matematika. Tanpa usaha 
segala sesuatu sulit untuk kita dapatkan. Oleh karena, itu berbagai upaya selalu dilakukan untuk mewujudkan tujuan tersebut.

Dalam proses pembelajaran di sekolah, siswa akan kesulitan menyelesaikan suatu masalah berupa soal-soal yang baru yang dituntut penyeselsaiannya dengan cara baru yang membutuhkan adanya kreativitas.Menurut pengamatan peneliti di dalam kelas VIII SMP N 1 X Koto Di Atas pada bulan maret2018, terdapat siswa yang terdiam dan kemudian bertanya pada teman sebelahnya ketika guru memberikan materi pelajaran secara lisan. Siswa tersebut meminta temannya untuk menerangkan kembali penjelasan guru. Terdapat juga siswa yang meminta guru untuk menuliskan contoh soal dan jawabanya di papan tulis dan juga ada siswa yang diam ssaja tetapi ketika ditanya guru siswa tersebut tidak bisa menjawab dan terdapat banyak siswa dalam menyelesaikan permasalahan matematika hanya mengerjakan seperti apa yang diberikan oleh guru mereka.

Hal ini terlihat ketika mereka mengerjakan soal di papan tulis. Ketika permasalahan yang dihadapinya agak berbeda penyajiannya meraka merasa kesulitan untuk menyelesaikannya. Selain itu, cara penyelesaian permasalahan matematika setiap siswa terlihat homogen dan tidak ada yang mengerjakan soal dengan cara penyelesaian selain yang diajarkan guru karena takut salah. Hal ini dikarenakan cara berfikir siswa yang masih bersifat konvergen. Oleh sebab itu, diperlukan kreativitas sehingga siswa dapat memilih dan menerapkan cara yang tepat guna menyelesaikan permasalahan yang dihadapinya dengan benar. Kreativitas adalah kemampuan seseorang untuk menghasilkan komposisi, produk atau gagasan apa saja yang pada dasarnya baru dan sebelumnya tidak dikenal pembuatnya. Selain itu, kreativitas juga mencerminkan pemikir yang divergen yaitu kemampuan yang dapat memberikan bermacam-macam alternatif jawaban. Pada akhirnya hasil belajar diharapkan dapat optimal.

Kreativitas adalah suatu kemampuan yang tersusun dan tidak sederhana serta terdiri dari faktor-faktor yang dapat menambahkan kemampuan berkreasi, seperti kemampuan untuk memperbaharui sesuatu yang sebenarnya telah diketahui dan disepakati, kemampuan untuk cepat tanggap terhadap segala prinsip baru, kemampuan untuk fleksibel dan berkreasi secara bebas dan kemampuan untuk tanggap terhadap permasalahan-permasalahan yang di alami seseorang (Amal Abdussalam Al-Khalili, 2005).

Menurut Cosmides dan Tobby dalam Robert L Solso, memberikan argumen yang mengenai fungsi kreativitas yang bertolak dari ide fungsi kreativitaas adalah menciptakan, melihat dan memahami sehingga dapat membantu manusia dalam berlatih dalam menghadapi kejadiankejadian yang nyata. Pada suatu saat nanti keinginan untuk menciptakan maupun memandang sebuah kreasi akan membantu dalam mempengaruhi prilaku fungsional lainnya dan menurut Pinker dalam Robert L Solso, mengemukakan baha funfsi kreatif adalah sebagai hasil sampingan (by-product) dari sifat-sifat yang fungsional lainnya seperti pemahaman bahasa dan menginterprestasi visual. Selain itu fungsi-fungsi kreativitas adalah bisa memahami dunia melalui belajar, seni dan sebagainya (Robert L Solso,dkk, 2007).

Indikator dari kreativitas diantaranya ketangkasan, fleksibilitas, orisinalitas, elaborasi(Abdussalam Al-Khalili, 2005).

Hasil belajar adalah sesuatu yang diperoleh seseorang setelah melakukan kegiatan belajar. Hasil belajar tampak setelah terjadinya perubahan tingkah laku pada diri siswa, yang dapat diamati dan diukur dalam bentuk peningkatan dan pengembangannya lebih baik dibandingkan dengan sebelumnya. Misalnya dari tidak tahu menjadi tahu. Hasil belajar dapat diketahui dengan menggunakan salah satu indikator yaitu tes. Hasil ini kemudian dianalisis oleh guru dan diberikan penilaian. Tujuan penilaian adalah untuk mengetahui siswa mana yang berhak melanjutkan pelajaran karena sudah berhasil menguasai meteri pelajaran dan siswa mana yang belum bisa menguasai materi pelajaran. Seta bertujuan untuk mengetahui apakah metode mengajar yang digunakan sudah tepat atau belum (Suharsimi Arikunto, 2007). 
Kreativitas yang di maksud adalah (1) Ketangkasan, yaitu kemampuan untuk menghasilkan pemikiran atau pertanyaan dengan jumlah yang banyak, (2) Fleksiibilitas, yaitu kemampuan untuk menghasilkan banyak macam pemikiran dan mudah berpindah dari jenis pemikiran tertentu kepada jenis pemikiran lainya, (3) Orisinalitas, yaitu kemampuan untuk berpikir dengan cara yang baru dan untuk mengahasilkan pemikiran-pemikiran jenius yang lebih banyak daripada pemikiran yang telah menyebar, (4) Elaborasi, yaitu kemampuan untuk menambah hal-hal yang baru atas pemikiran-pemikiran.

Dari penjelasan di atas, peneliti ingin mengetahui apakah ada hubungan antara kreativitas siswa dengan hasil belajar matematika siswa kelas VIII SMP N 1 X Koto Di Atas Kabupaten Solok Tahun Pelajaran 2017/2018. Diharapkan dari penelitian ini adalah secara teoritis dapat memberikan sumbangan kepada pembelajaran matematika, utamanya dalam mengetahui adakah hubungan yang signifikan kreativitas dengan hasil belajar matematika

\section{METODE}

Jenis penelitian ini termasuk jenis penelitian korelasional dengan sifat penelitian ex post facto ( Arikunto, 2000). Penelitian ini dilakukan di kelas VIII SMP N 1 X Koto Di Atas tahun pelajaran 2017/2018 dengan populasi 77 orang, maka penelitian ini adalah penelitian populasi.Dalam penelitian ini yang menjadi variabel bebas adalah kreativitas siswa kelas VIII SMP N 1 X Koto Di Atas Kabupaten Solok Tahun Pelajaran 2017/2018 (X) berupa angket yang disusun dalam bentuk intrumen angket dengan jumlah 36 pernyataan dan variabel terikatnya adalahhasil belajar matematika siswa kelas VIII SMP N 1 X Koto Di Atas Kabupaten Solok Tahun Pelajaran 2017/2018 (Y) berupa hasil ujian murni semester genap 2017/2018.

Sumber data dalam penelitian ini adalah:

1. Data Primer dalam penelitian ini adalah kreativitas yang diperoleh dari angket yang dibuat oleh peneliti

2. Data sekunder dari penelitian ini adalah data absensi siswa yang menjadi populasi dan nilai murni ujian semester genap siswa.

Teknik pengumpulan data yang digunakan dalam penelitian ini adalah :

1. Metode Kuesioner (angket)

Metode ini merupakan cara pengumpulan data dalam bentuk sejumlah pertanyaan atau pernyataan tertulis yang digunakan untuk memperoleh informasi dari responden dalam arti laporan kepribadian atau hal-hal yang diketahuinya (Arikunto, 2000).

2. Metode Dokumentsi

Metode ini digunakan untuk mengetahui hasil belajar siswa pada mata pelajaran matematika.

Angket yang digunakan adalah jenis angket tertutup yaitu suatu angket yang pernyataannya dan alternatif jawabannya telah ditentukan sehingga responden tinggal memilih jawaban yang diinginkan. Angket kreativitas digunakan untuk mengetahui tingkat kreativitas setiap siswa dalam pembelajaran matematika. Dimensi-dimensi yang digunakan meliputi dimensi kognitif baik konvergen maupun divergen. Angket kreativitas siswa terdiri atas beberapa pernyataan. Butir angket dinyatakan dalam dua bentuk yaitu pernyataan yang bersifat positif dan bersifat negatif.

Dalam hal ini jumlah pernyataan angket kreativitas terdiri dari 36 pernyataan yang dibagi menjadi 18 positif dan 18 negatif. Untuk hasil belajar diperoleh dari hasil ujian semester genap $2017 / 2018$

Dalam hal uji coba angket terdiri dari dua ha yaitu validitas dan reabilitas. Pengujian skala angket kreativitas ini menggunakan uji coba terpakaidengan alasan skala yang dipakai sudah mewakili setiap indikator, oleh karena peneliti menyediakan beberapa item dari setiap indikator jadi, jumlah item yang gugur dan valid yaitu 26 item yang valid dan 10 yang tidak valid. Setelah melalui proses pengumpulan data selanjutnya dilakukan analisis data yang meliputi pengolahan 
data ( Uji Normalitas dan Uji linieritas ), pengujian hipotesis.Data yang diperoleh secara manual dianalisis dengan bantuan software SPSS.

\section{HASIL DAN PEMBAHASAN}

Persyaratan untuk melakukan hipotesis data maka data harus terlebih dahulu di uji normalitas dan uji linieritasnya

Tabel 1. Uji Normalitas dua variabel

\begin{tabular}{ccc}
\hline Variabel & $\boldsymbol{L}_{\boldsymbol{t a b} \boldsymbol{b}}>\boldsymbol{L}_{\mathbf{0}}$ atau $\boldsymbol{L}_{\boldsymbol{t a b}}<\boldsymbol{L}_{\mathbf{0}}$ & $\begin{array}{c}\text { Normal atau Tidak } \\
\text { Normal }\end{array}$ \\
\hline Kreativitas & $0,100969>0,0653$ & Normal \\
Hasil belajar & $0,100969>0,0990$ & Normal \\
\hline
\end{tabular}

Tabel 2. Uji Normalitas dengan spss

Kolmogorov-Smirnova

\begin{tabular}{lccc}
\hline & \multicolumn{1}{c}{ Statistic } & Df & Sig. \\
\hline Kreativitas & .065 & 77 & 032 \\
h.belajar & .099 & 77 & 019. \\
a. Lilliefors Significance Correction & &
\end{tabular}
normal

Dapat dilihat sig dari dua variabel tersebut $<0,05$ dapat dikatakan data berdistribusi

\section{Uji linieritas antara kreativitas dengan hasil belajar}

Apabila $F_{\text {hitung }}<F_{\text {tabel }}$ dapat dikatakan data berpola linier dipenelitian ini diperoleh nilai $F_{\text {hitung }}=1,165078$ sedangkan nilai $F_{\text {tabel }}=1,74042$, pada taraf signifikan $95 \%$ atau $a=$ 0,05 , hal ini menunjukkan bahwa nilai $F_{\text {hitung }}<F_{\text {tabel }}$ sehingga dapat disimpulkan bahwa data berpola linier

Tabel 3. Uji Linieritas dengan software spss

\begin{tabular}{|c|c|c|c|c|c|c|c|}
\hline & & & Sum of Squares & & Mean Square & $\mathbf{F}$ & Sig. \\
\hline \multirow[t]{5}{*}{$\begin{array}{l}\text { kreatif } * \\
\text { hasil }\end{array}$} & \multirow[t]{3}{*}{$\begin{array}{l}\text { Between } \\
\text { Groups }\end{array}$} & (Combined) & 2739.399 & 0 & 91.313 & 1.932 & .022 \\
\hline & & Linearity & 687.880 & & 687.880 & 14.554 & .000 \\
\hline & & $\begin{array}{l}\text { Deviation } \\
\text { from } \\
\text { Linearity }\end{array}$ & 2051.519 & 9 & 70.742 & 1.497 & .009 \\
\hline & \multicolumn{2}{|c|}{ Within Groups } & 2174.133 & 6 & 47.264 & & \\
\hline & \multicolumn{2}{|c|}{ Total } & 4913.532 & 7 & & & \\
\hline
\end{tabular}

Dapat dilihat dari tabel di atas sig $<0,05$ maka didapat dikatakan data perbola liner.

\section{Uji hipotesis}

Hipotesis penelitian ini dalm penelitian terdapat hubungan signifikan antara kreativitas siswa dengan hasil belajar matematika siswa kelas VIII SMP N 1 X Koto Di Atas Kabupaten Solok Tahun Pelajaran 2017/2018. Pengujian hipotesis dilakukan dengan uji statistik koefisien korelasi pearson, dimana terlebih dahulu.Sebelum dilakukan uji statistik koefisien korelasi pearson, 
terlebih dahulu dilakukan perhitungan dengan rumus product moment untukmendapatkan nilai $r$, dimana didapatkan bahwa derajat hubungan antara kalkulus diferensial dengan kalkulus peubah banyak bernilai 0,374 atau $r=0,374$. Ini artinya, terdapat hubungan yang rendah antara kreativitas dengan hasil belajar matematika. Dari koefisien korelasi sederhana tersebut, diperoleh nilai koefisien determinasi sederhana sebesar 13,69\%, yang artinya variabel $X$ atau kreativitas siswa memberikan sumbangan sebesar 13,69\% terhadap variabel $Y$ atau hasil belajar matematika. Koefisien determinasi tersebut menjelaskan bahwa jika nilai salah satu variabel naik, maka nilai variabel lainnya juga akan naik, atau sebaliknya.

Setelah dilakukan uji statistik koefisien korelasi pearson, didapatkan nilai $Z_{0}=3,225585$ sedangkan nilai $Z_{\text {tabel }}=1,96$, pada taraf nyata $a=0,05$, hal ini menunjukkan bahwa $Z_{0}>$ $Z_{\text {tabel }}$ maka dapat disimpulkan bahwa terdapat hubungan signifikan antara kreativitas siswa dengan hasil belajar matematika siswa kelas VIII SMP N 1 X Koto Di Atas

\section{Uji hipotesis dengan software spss}

Sebelum masuk ke uji hipotesis Pertama yang dilakukan adalah menentukan hipotesis yang dirumuskan sebagai berikut

$\mathrm{H}_{0}$ :tidak ada hubungan signifikan antara kreativitas siswa terhadap hasil belajar matematika siswa kelas VIII SMP N 1 X Koto Di Atas Kabupaten Solok Tahun Pelajaran 2017/2018.

$\mathrm{H}_{1}$ : ada hubungan signifikan antara kreativitas siswa terhadap hasil belajar matematika siswa kelas VIII SMP N 1 X Koto Di Atas Kabupaten Solok Tahun Pelajaran 2017/2018

Ketentuan yang digunakan dalam penentuan hipotesis ini adalah jika sig $<0.05$ maka $\mathrm{H}_{0}$ ditolak dan sig > 0.05 maka $\mathrm{H}_{0}$ diterima

Tabel 4. Correlations

\begin{tabular}{|c|c|c|c|}
\hline \multirow{4}{*}{ Kreativitas } & \multirow[b]{2}{*}{ Pearson Correlation } & kreativitas & h.belajar \\
\hline & & 1 & $.374^{* *}$ \\
\hline & Sig. (2-tailed) & & .001 \\
\hline & $\mathrm{N}$ & 77 & 77 \\
\hline \multirow[t]{3}{*}{ h.belajar } & Pearson Correlation & $.374^{* *}$ & 1 \\
\hline & Sig. (2-tailed) & .001 & \\
\hline & $\mathrm{N}$ & 77 & 77 \\
\hline
\end{tabular}

**. Correlation is significant at the 0.05 level (2-tailed).

Dilihat dari tabel korelasi terdapat bahwa sig $0.001<0.05$ maka $\mathrm{H}_{0}$ di tolak dan $\mathrm{H}_{1}$ di terima. Dalam hal ini menyatakan bahwa terdapat hubungan signifikan antara kreativitas siswa dengan hasil belajar matematika siswa kelas VIII SMP N 1 X Koto Di Atas Kabupaten Solok tahun pelajaran 2017/2018

\section{KESIMPULAN}

Berdasarkan hasil penelitian dapat disimpulkan bahwa terdapat hubungan yang signifikan antara kreativitas dengan hasil belajar matematika siswa kelas VIII SMP N 1 X Koto DI Atas Kabupten Solok tahn pelajaran 2017/2018. Hasil penelitian diperoleh $Z_{0}=3,225585$ dan $Z_{\text {tabel }}=$ 1,95996398 , pada taraf nyata $a=0,05$. Hal ini menunjukkan bahwa $Z_{0}>Z_{\text {tabel }}$ yang berarti 
bahwa terdapat hubungan signifikan antara kreativitas siswa dengan hasil belajar matematika siswa kelas VIII SMP N 1 X Koto Di Atas Kabupaten Solok Tahun Pelajaran 2017/2018.

\section{REFERENSI}

Alkahfi, Amal Abdussalam, (2005). Mengembangkan Kreativitas Anak. Jakarta: Pustaka Al-Kautsar.

Arikunto, Suharsimi.(2000). Manajemen Penelitian. Jakarta : Rineka Cipta.

Arikunto, Suharsimi. (2007). Manajemen Penelitian.Jakarta: Rineka Cipta.

Suherman,Ermandkk.(2003). Strategi Pembelajaran Matematika Kontemporer. Bandung JICA: Universitas Pendidikan Indonesia. 